\title{
Muséologies
}

Les cahiers d'études supérieures

\section{Research-creation as a curatorial challenge: An interview with John Zeppetelli}

\section{Carmela Cucuzzella}

Volume 8, numéro 1, 2015

Réflexions sur la pratique curatoriale et la recherche-création

URI : https://id.erudit.org/iderudit/1034614ar

DOI : https://doi.org/10.7202/1034614ar

Aller au sommaire du numéro

Éditeur(s)

Association Québécoise de Promotion des Recherches Étudiantes en Muséologie (AQPREM)

ISSN

1718-5181 (imprimé)

1929-7815 (numérique)

Découvrir la revue

Citer ce document

Cucuzzella, C. (2015). Research-creation as a curatorial challenge: An interview with John Zeppetelli. Muséologies, 8(1), 131-142.

https://doi.org/10.7202/1034614ar

Tous droits réservés (C Association Québécoise de Promotion des Recherches Étudiantes en Muséologie (AQPREM), 2016
Ce document est protégé par la loi sur le droit d'auteur. L'utilisation des services d'Érudit (y compris la reproduction) est assujettie à sa politique d'utilisation que vous pouvez consulter en ligne.

https://apropos.erudit.org/fr/usagers/politique-dutilisation/ 
Entrevue

\section{Research-creation as a curatorial challenge: an interview with John Zeppetelli}

Carmela Cucuzzella 
Contemporary Art museums are directly faced with the growing challenge of exhibiting research as a result of a creative process, or what is often referred to as in Quebec as research-creation. One of the many challenges is establishing a dialogue and informing viewers of the underlying reflections involved in a research project. Given this, what are the options available to curators? In the context of a creative practice led research, are new modes of dissemination and cultural mediation needed to accommodate the often complex theoretical undertaking?

How would you define research-creation and how would you compare this work with contemporary artwork?

John Zeppetelli - I would like to hear how you define research-creation for the purposes of this interview and for the purposes of your journal?

From a research perspective, we often define research-creation as practice-based research. More specifically, I would say that it is an activity where the creative process, whether it is in art, design, performance, literature, etc. is situated within a core of research activity. The outcome of a research-creation activity is creative work that is critically informed. However, not all art or design practice is based in research, and I would say that work that is limited to a self-analysis or interpretation of one's own work cannot be considered as research-creation.

In Quebec there is a strong culture of research-creation projects coming out of university, either from disciplines of fine art, design or cultural studies. How is this phenomenon impacting the museum space today?

J.Z. It's a very relevant question and is now a prominent category in funding agencies, for example Canada Council for the Arts. For example, there is a practice-based $\mathrm{PhD}$ in art making at UQAM, and of course as a museum (The Musée d'art contemporain de Montréal) we're invested in the production of knowledge through artworks and through material objects. So this is a central question.

One could think of art as an absurd activity or even as a luxury. But for me it is essential, it's not a luxury at all, but rather, something fundamental-one of the great spheres of activity that we have, and a compelling belief system. It's what will endure over generations, and not coincidentally, every major city in the world has a museum at its centre. We're totally invested in this art production as a basis for the production of knowledge, where artists are considered incredibly important thinkers who contribute to the wider cultural or social conversation, in ways similar to philosophers, journalists or researchers. The contribution of artists to the conversation and to the discourse, is in material objects and their aesthetic explorations. Artists offer objectifications of experiences of the world in the form of material objects, of installations or whatever we may define as contemporary art at the moment. That objectification takes the form of an artwork, which is endlessly redefined. When Duchamp famously took a urinal into a gallery flipped it over and signed 
it as an art object, an object without prior aesthetic value or interest: essentially a mass-produced object, completely un-invested with an aesthetic experience and yet the artist designates it as, declares it, art. That gesture, in conjunction with the museum director who allows that object to be defined as artwork, signifies a very important moment. The object was invested with a declarative idea and opened up a fundamental conversation. This object must then be read as an artwork, because the director, in cahoots with the artist and the surrounding intellectual climate, has placed it in a museum: a precinct devoted to the experience of art. The fact that the director is telling a visitor that this is an art object simply by placing it in a museum forces them to read it in a particular way. The question being asked is, "why should I consider this found object, this mass-produced object with no aesthetic value whatsoever, as an art object?" The answer is because of the idea that was invested in it — about industrial production and aura, about legitimate authorship, about subjectivity, about the ever-changing role of art, about art's reception, its multiple contexts and readings etc. And of course that particular event opened the floodgate to thinking about art as a linguistic substitute and other connotations of that idea. So the museum is very much invested in artwork as an object that embodies this idea of research.

Is the MACM linked in any way to the diverse research-creation programs in universities? Or does the museum participate in programs that sustain research-creation? For example the MoMA has the Global Research Program, the CCA has curatorial opportunities for up and coming curators.

J.Z. Sadly we don't. And I would love to develop it more, but with dwindling budgets, basically we're struggling just to get our exhibitions up and going with a minimal amount of educational enhancements around them. We used to have in the basement gallery a multimedia research residency project where people like Robert LePage were able to initiate and produce a play. And there were other great events, like Francois Girard did a project there as well. But sadly we don't have the budget for that. Honestly, we feel that every curatorial initiative is a kind of research project.

Would you say that the contemporary artworks exhibited at the MACM are analogous to the objects that are the product of a research-creation project?

J.Z. Yes, I would think so. Artworks are made and offered for all kinds of reasons: sometimes there's an ideological position, sometimes artists make work within traditions, within an accrued history, and mobilize their thinking to renew the tradition or reinvent it somehow or to try and find a new form within these traditions. Sometimes they want to draw the experience of the world. Artists have to be attentive to their various interactions. Personally there are many positions one can have and it's not just the western sort of taste, because of course taste and judgement are very complex issues. But what compels me in an artwork is that there is an embodiment that allies an aesthetic consideration or a compelling 
formal consideration with an urgent social, political or psychological message. So when these come together and are fused in an artwork, this is what I respond to.

I just hung a new collection show downstairs, at the centre of which is a new acquisition that I'm very proud of, a work by Thomas Demand. I've added works from the permanent collection, that have been in the collection for years, so I call it "Nouveautés et autres obsessions". And you can see the position I am taking in terms of my relation to the objects in this collection. They are not objects I've plucked out of an ideal archive, but they are objects I've carefully selected from our own strong collection of 8,000 works of art. You can get a sense of what I want to articulate downstairs. At the center of the display is the work by Thomas Demand. I don't know if you're aware of his work, but he's a German photographer and an incredibly philosophical artist because he is inspired by images that he collects from the media stream. For example, an image off the Internet or from a newspaper, that is always two-dimensional. The picture we have downstairs shows you the inside of a museum vault in Paris with many paintings stacked against the wall. You cannot see the details of the paintings. An image of a museum vault within a museum is already a kind of self-reflexive moment. But what he does that is beautifully philosophical is that he will take an image from the media, in this case it's a photograph of a vault in Paris - a photograph that the French police have taken at the Wildenstein Institute. While the French police were investigating some other act of possible criminality, they came across this vault where lots of paintings were stored. The French police took this photograph by accident, and realized that these paintings, hidden in this vault, were declared lost or stolen by the Wildenstein's. So of course they will be investigated. Thomas Demand is saying that he is interested in these images that have a political intrigue, images in the real world. He selects this two-dimensional picture, recreates it in his studio as a sculpture with a team of assistants, using paper and cardboard. Sometimes it takes weeks to complete. Using scissors, glue and coloured paper, he recreates the image as precisely as possible, without people. The work begins with a photograph in the media, which then becomes a sculpture in his studio, which the artist then carefully lights. The end result is a photograph of the sculpture he just created, which began its life as a photograph. It's a photograph that is triply removed from reality. So what you see, is a very real looking photograph, yet is not entirely what you think it is. When you look at the finished photograph, you realize that something is not quite right, that it feels rather artificial, yet very real. The incredible thing about this artist is that he will recreate an image that depicts, for example, a two-story building, as a sculpture in the studio. If the building is two stories high, he will recreate it using paper and cardboard. In this case, this is a 50-foot vault recreated in paper and cardboard in his studio, at one-to-one scale. The scale of the final photograph is also extremely large. The viewer has a real sense of walking into the space when viewing the photograph. The sculpture is ephemeral, made of cardboard, so it won't survive and is destroyed after the photograph is made. The end 
result is a very perverse detour, from a media photograph, to a sculpture, back to a photograph, and immortalized in a museum, a photo that could have been completely lost in the media stream.

So in this rich, process-oriented work, how would you, as a museum curator and director, be able to show the public that this process is occurring? The public is led to interpret art from each of their backgrounds. How much of the artist's reflection regarding the process and its critique to the larger conversations, are you able to make accessible to the public?

J.Z. Well we try to include as much didactic wall panels as possible. In this case, because the Thomas Demand image is at the very centre of the exhibition, it's the main, central subject for the introductory wall panel. The public can read the main proposition of the exhibition and each individual work in the exhibition will also have a short explanatory text.

We don't want to make it too didactic and that's the interesting part because we want to create a seamless flow, an experience that is unified. We want the public to be able to explore the individual qualities of each work, so every single image, or painting or sculpture on display in the collection or show will have an explanatory wall text. It won't be exhaustive, but it may generate further interest in the viewer. Visitors may also just glean this information. Some artists, like Thomas Demand, when doing a solo display of his work, actually prefers not to have wall panels, because an integral part of his work is the interpretation, even if he produces something that is highly complex and circuitous from a photograph to a sculpture, lights it, and photographs the sculpturethis kind of strange uncanny meditation around authenticity, memory and the status of the real.

In this specific case, is there a commentary or critique by the artist that can be offered to the viewers regarding this process or even justification of the reproduction of a mediatized image? Or is the artist photographing the reproduction of the reproduction of the reproduction, for the sake of the reproduction process, in a kind of Walter Benjamin continuum?

J.Z. Yes, it's a Benjaminian idea. He makes allusions to all kinds of things, the aura of a photograph, the aura of an artistic experience versus something like the aura of this mysterious process. Because this is a general artwork display, and I have full authority over the works we own as a museum, I can put wall panels or texts around works. But if we were working with the artist himself for a solo exhibit in a larger exhibition, he would probably not want wall panels, because he prefers the visitor to come in, interpret the work for himself, take the experience home and let the images work retroactively. This artist does not necessarily want to absolutely fulfill every expectation in a consumer driven way, where the viewer of the museum has to absolutely walk away with a satisfied, completely tied up version of what they've just experienced. He prefers a level of ambiguity in the reception, one that may frustrate and haunt 
you. That haunting will make the viewer want to investigate further, something will be triggered retroactively that may further contribute to the reception of the work of art.

And that's an interesting way to think in terms of our responsibility as museum curators towards viewers. It is a little more complicated because we want to make the experience of contemporary art as attractive as possible. We have a mandate to bring art to the people, to make it as widely available and as widely understood as possible, to enlist as many people as we can. In these sometimes difficult, absurd, and sometimes, even revolting works - there are some works of art that literally play on aggressing the viewer, and we need to package these in a way that is compelling. And this raises our audiences' experiences.

As a curator of an institution that must accommodate a large audience with huge blockbuster shows, how do you present work that is interesting to the spectrum of audiences, from academics, to artists, to the general public? For example an artist or an academic has the capacity to interpret on a different level than the general public, so how can you accommodate these differences?

J.Z. Well, it's interesting you ask that now, because this is the first block of exhibitions that I am almost exclusively responsible for. I've been here for a year and a half and I had to accompany a program that I inherited. Whereas now we've got three exhibitions in place that I agreed to, that I green-lit. In two of the cases, I actually sought out and brought in side curators. So as the director and the chief curator of the museum, I take full responsibility for all the choices. First of all, let me briefly explain the museum. The galleries to the south, which constitute half the museum, are devoted to the collection. The galleries to the north are devoted to temporary exhibitions. There are four galleries in the north and four galleries in the south, and then we have a gallery in basement, which is usually media work.

Until a day or two ago we had a beautiful film running - a very straightforward documentary by Allan Sekula, a photographer. He is a Marxist artist who is invested in aesthetic experimentation but only so far in as it can deliver a political message. It's a work called 'The Forgotten Space' which is about the daily transportation of hundreds of thousands of container ships across our oceans that constitute ninety percent of world trade. He wanted to investigate this because previously he completed a project on the fishing industry on how the container itself, the unit within the container ship, has standardized world trade. Every port has to accommodate this unit of trade by placing it on a truck or rail for further distribution. It's a beautiful essay on how these large ports have affected labour, labour conditions, social conditions and environmental conditions.

This movie was in the basement and I felt it was a nice metaphor. We had this strong Marxist approach whereas on the exhibition floor, we have two exhibitions, one which is a people friendly show, by Sophie 
Calle. She is a very interesting French conceptual photographer. What I'm trying to do with the two exhibitions that we have on view now is precisely educate at many levels. Sophie Calle is a very widely known artist who has been working for the last 30 years and became famously notorious because of projects where she invaded peoples privacies, a performance, and almost theatrical act. This is contrasted by other artists' work that is more metaphorical, that requires more from the viewer.

In the Sophie Calle example, which is a series of material objects that are the result of an almost theatrical performance, would you consider this artwork as a research-creation project?

J.Z. Yes. In one among many projects that she completed, she followed people around the streets of Paris, just as an exercise. Specifically, she followed a man for a couple of days and then lost sight of him. Then one night quite by chance, she realized that she bumped into him at a gallery opening and overheard that he was going to Venice the next day. She goes to Venice the next day, calls 300 hotels, since she knew this man's name and found out where he was staying. She basically stalked him for two weeks, photographing him. It was a very complex investigation around what can be perceived as an obsession. There was never any contact. She didn't want to seduce him, she just wanted to go through this exercise, to follow another person's life and see where it would take her. She produced a book of photographs.

Another example of Sophie Calle's projects is one where she finds an address book on the streets of Paris. She photocopied the contents before sending the address book back to its owner, telling him "by the way I found your address book, here it is". She then systematically called every single name listed in the book, and then published her findings. At the time, she had an art project in the French daily called Libération, where she was offered a half-page art intervention every day for the month of August. This newspaper has a circulation of millions of people. She took advantage of this project to publish her findings from this assignment. She interviewed all the people from the address book who agreed to speak with her, and published her findings in this half page of the newspaper. Fortunately for her, the man who was the owner of the address book was on vacation for the first two weeks of August and didn't realize this was happening. When he got back to Paris and read Libération, he noticed a project called 'L'homme au carnet' and discovered that the project was about him. He immediately called the newspaper and had it stopped. This was a very daring, powerful project, where she was able to sketch out the identity of an unknown man by interviewing other people.

Her work is currently on view downstairs with two projects that are interrelated, since both were set in Istanbul. She worked with an agency there to locate people who had lost their sight suddenly. She found them, asked if they would submit to an interview and if she could take their portrait. She then asked each of them to describe the last image they saw before going suddenly blind. Some of the stories are incredibly touching. She took a picture of the blind person and asked them to visualize their last image. She has a text panel explaining in the most economical 
and beautiful language, the last image of each of these people. Her work has always consisted of the relationship between text, imagery and performance-this conjunction between a story and in this case a real story of a lived experience. We are fortunate to have been able to acquire one of these for the collection. It shows two side views of a man against the sea. There is also an image of a very plain brown patterned sofa. He didn't lose his sight suddenly. So the last image for him is the image that he misses the most, which is not being able to see his three children sitting on that sofa, all he sees is this darkness. So as a viewer of this piece, what we see is an image of an empty sofa, the portrait of the man and a text explaining it, so beautiful. A poignant expression of loss.

As a counterpoint, to this loss of sight project is another project that she did in Istanbul. At the time Istanbul was the European city of culture. She was told of an article published in a Turkish daily that identified a category of people that live in Istanbul and had never been to the seaside- a city surrounded by bodies of water. Because of severe misfortune and socio-economic conditions they never had this opportunity. The writer of this article was shocked and horrified about this. Sophie Calle sought out some of these people and asked them, "Can I take you to the seaside for the first time in your life, if you would agree?” During the ride to the seaside, she asked them to keep their heads down, and then asked them to lift their heads up and open their eyes when they got there. She witnessed this, and filmed their first time at the seaside.

So on one side of the exhibition you have this melancholy loss of imagery, countered by the first apparition of something. Both are extremely melancholic in the sense that one is about loss of sight and the other is about people who live under such severe economic hardship that they are unable to go to the seaside in a city that is surrounded by water. This show is attracting a lot of people. Sophie Calle was on 'Tout le monde en parle'. She was interviewed by Vice magazine, one of the biggest media outlets in the world.

Sophie Calle's work is very popular and publicly accessible because of the emotional experiences it engenders. Even if it is at times confrontational, it is definitely embedded in a conceptual conversation. Would you consider Sophie Calle's projects as research-creation projects?

J.Z. She has a simple idea, to present a suite of photographs around blindness in a visual arts context, because art is about the visual, about what can be seen. This project was inspired by another project she completed 25 years ago, also around the blind. In fact we make reference to that initial project in a side room. In that project, she had asked people who were born blind to describe their greatest image of beauty. Which is almost a provocation when you think about it, in fact, almost slightly disturbing and wicked, almost insulting. She began by asking one blind person, "Would you mind if I ask you, since you've never been able to see, do you have an idea of what beauty is?", to test if this kind of questioning could work. The blind person responds, "Absolutely, for me it's the sea, the sea as far as you can see." In French, its much more beautiful "la mer, 
la mer à perte de vue", the sea in its infinity. She realized then that she was on the right track, that she wasn't insulting anyone, and that blind people do have an idealization of beauty. But what a paradox: suggesting to a blind person to think about an image of beauty. Sophie Calle is doing very courageous work. She follows people around, will consciously seek them out just to take their photograph and test their limits about what is private, what is public and what is acceptable. So there's a level of courage and provocation that I am happy somebody is doing.

So you get huge audiences for her shows because she is well known, her work is fairly easy to read, and has a strong media presence. How do you get the audiences for artists that have not been so mediatized, for artists that have a much larger contribution to the conversations about art, society, politics, economy, etc.?

J.Z. Yes, we've had huge audiences for her show. Another artist we currently have on display, that some may consider equal or even superior to Sophie Calle, but is not well known, is much more difficult in terms of attracting viewers of all types. His name is Simon Starling, and I think he has an equally brilliant show. It is very different because it demands a lot more from the viewer. Every object in the show seems to have unsuspecting associations. He's a wonderful conceptual artist who seems to enlist all kinds of narratives around geopolitics and economy. For example, there's a fantastic sculpture, which consists of two large pieces of marble. One piece was quarried in China, the other was quarried in Tuscany, its Carrara marble. The Chinese piece is very roughly hewn; it's a block, it's massive and weighs like two tons. The Italian version is half the weight, smaller in volume, but identical in shape to the Chinese version, because they took a digital scan of the Chinese block and digitally cut the Italian block. They are both suspended in the gallery space. So viewers see these huge menacing potentially dangerous blocks of marble hung on a pulley system in improbable balance because they seem equal in weight. But the way that the artist positioned the blocks, when you enter the gallery and with the perspective and foreshortening, they look like they're the same size. It's only when you move around them do you realize that there is a much smaller one and a much bigger and heavier one. The artist's point is that they both have the same market value. So it's a wonderful kind of conversation and debate on the 'Made in China' versus the prestigious European marble.

There is also a link to this idea in the Adrian Paci film, which is also shown in my collection show. Adrian Paci is an Italian artist of Albanian origin who has been living in Milan for the last 26 years. We just acquired one of his films called The column. The column is about Chinese workers producing a Greco-Roman marble column as they transport it to their client in Europe. The film follows the entire work process, from the quarrying in China, to the transport of this big huge block of marble on a big ship, then the workers coming onto the ship, and the journey across the ocean to Europe as these extremely skilled people make what in many ways is the apogee of western culture. 
Yet a growing number of artists tackle research in a way that seems to evacuate or at least avoid any form of theoretical discourse. In your opinion how do these practices affect the art realm and the museum collections, and maybe even your own collection?

J.Z. Well let's just say that from my perspective, and I'm not saying it's the only perspective to adopt, but I think museum curators are less interested in exclusively formal experiments. By formal experiments I mean, with respect to painting for example, questions about what is intrinsic to painting. This is in many ways a modernist painting [referring to a painting in his office], in the sense that it is pure abstraction. It's about the flow of paint, the gesture, the support of the canvas, the all-over, and calls attention to its surface and calls attention to the paint itself, to the materials of its own making, it's a self-referring celebration of itself, it doesn't take into account anything other than the experience of paint. So in many ways that is a typical modernist object. However, I'm not suggesting that I'm not interested in formalism. I see it as a pleasing aesthetic experience. I could make other arguments for this object. Formal play, some people would argue, is deeply wonderful and liberating, because it offers pleasure, taps into the mysterious unconscious and is a hopeful experience, is an experience that enlists you in all kind of other things. It's not without qualities, it's just something that, you know, I don't particularly celebrate myself, if it's just that. But fortunately we have a big enough museum to be able to present all kinds of work. As I said with Simon Starling and Sophie Calle-it's a really interesting display of Sophie Calle, an interesting conceptual artist, with an immediate emotional impact, whereas Simon Starling is much more cerebral, you have to take the time to read the text, and look at the work and parse it, then the rewards are magnificent and huge, but you have to make an investment.

You've provided me with quite a nice spectrum of different kinds of art work, one with a deep engagement of the viewer because of the more socio or geo political conversations the artist projects, others that require less engagement, all equally interesting in process and discourse. As a museum curator, what strategies do you use to help better understand the various types of work? J.Z. Wall text is absolutely essential for Starling.

What about exhibition strategies, which are so vital for a show like Starling? Besides wall text, how do you, on the one hand, catch the viewer's interest, and on the other reveal the artist's motivations and conceptual framework? Everyone wants to know what we're looking at, at least minimally, otherwise the museum experience can be quite alienating.

J.Z. Because the art works are not just a pretty landscape, which can be appreciated it for its loveliness, its quality of paint and brushstrokes, contemporary art is very implicated in so many other disciplines at the moment that it's really the embodiment of a very wide field of different practices. Contemporary art draws from the humanities, politics, sociology, and basically our position within contemporary art is that it's the result of a cross-disciplinary reflection, which takes form in a material 
objectification of some kind, with an aesthetic value that we ascribe to it, that we make an argument for. So that's the position that we take. A lot of commercial galleries show ostensibly contemporary art, which we deem to be irrelevant and not conducive to knowledge productionart that basically doesn't advance the redefinition of art, or how an aesthetic position can become a relevant position within society.

\section{If we consider the heterogeneity of art production: Sophie} Calle is very different from Starling, who is very different from Thomas Demand, this implies potentially renewed exhibition strategies from the museum curators themselves. Are these strategies ever exposed or do they need to be exposed?

J.Z. Well, you have to calibrate it carefully because you want maximum impact without giving too much away. But every exhibition is preceded by an introductory wall text that tells you who the artist is, what the essence-of the exhibition is. It is the case for both Sophie Calle, Simon Starling and my collection show. So there is a premise that kind of orients the viewer to receive the work in a particular way. Thomas Demand works within a tradition, he works within photography, it is obviously a photograph that you're looking at, and then only in a second moment you realize 'wow, this is a photograph of a sculpture'. Sculpture is a widely acknowledged tradition in the art world. It's not that every show is a massive departure from tradition. They're all grounded in recognizable fine arts traditions, that have been reimagined or that have been newly revisited. To show something fresh and new and interesting that can solicit you in the experience, it forces you to engage with it. 